\title{
Pathobiochemistry of Ammonia in the Internal Environment of Fish (Review)
}

\author{
M. SMUTNÁ ${ }^{1}$, L. VORLOVÁ $^{1}$, Z. SVOBODOVÁ 1,2 \\ ${ }^{1}$ Department of Biochemistry and Biophysics, Faculty of Veterinary Hygiene and Ecology, \\ University of Veterinary and Pharmaceutical Sciences, Brno, Czech Republic \\ ${ }^{2}$ University of South Bohemia České Budějovice, \\ Research Institute of Fish Culture and Hydrobiology, Vodňany, Czech Republic
}

Received June 6, 2001

Accepted June 19, 2002

\section{Abstract}

Smutná M., L. Vorlová, Z. Svobodová: Pathobiochemistry of Ammonia in the Internal Environment of Fish (Review). Acta Vet. Brno 2002, 71: 169-181.

In this study, the origin and pathways of detoxication of ammonia in the body of fish are analysed. Ammonia is toxic for an organism even in trace amount. The role of direct deamination of amino acids such as histidine, serine, asparagine and glutamine is emphasized with regard to ammonia production, the functional association of transamination and deamination is reflected in a transdeamination reaction, where the central role is played by the enzyme glutamate dehydrogenase. Furthermore, less known sources of ammonia occurring during natural restoration of body cells and tissues are discussed. Particularities of biochemical processes in fish, such as the non-existence of ureosynthetic cycle along with a sudden change of environmental conditions can easily disturb the balance between production and excretion. If the detoxication abilities of fish are exceeded, ammonia acts as a toxicant, thus leading to accidental mortalities of fish.

Transdeamination, purine cycle, locomotion, starvation, ammonium ion

Ammonia is the main final product of nitrogen metabolism in freshwater fish. A very small part of metabolic products is represented by urea. According to Wood (1993) ammonia represents $92 \%$ and urea $8 \%$ of the nitrogen excretion products in carp (Cyprinus carpio). Eighty eight $\%$ of ammonia and $7 \%$ of urea is excreted through the gills and $4 \%$ of ammonia and $1 \%$ of urea through the kidney. The balance between production and excretion of ammonia may be disturbed by various endogenous and exogenous factors (Lloyd 1992; Wood 1993). This results in most cases in a significant increase of ammonia levels in the blood and consequently in an ammonia autointoxication (Svobodová et al. 1986).

A new disease (toxic gill necrosis in carp) was described in the middle of the 1970s (Schreckenbach et al. 1975). The illness occurred in ponds with highly eutrophic water as a result of an imbalance within the aquatic environment of the ponds, particularly after a sudden and significant decrease in oxygen concentration. A multiple increase of ammonia levels in the blood plasma was the crucial diagnostic sign for the disease. Several authors elaborated measurements in order to prevent the occurrence of this disease (Hamory and Pocsi 1982; Hornich and Tománek 1983; Kovacs-Gayer 1984; Farkas and Olah 1986; Svobodová et al. 1986; Doege 1991). Presently we find toxic gill necrosis in carp rarely, almost exclusively when prevention in eutrophicated ponds in springtime is neglected.

On the other hand, cases of ammonia autointoxication in carp occurred frequently in recent years, when there is a sudden and significant decrease in water temperature or in oxygen concentration of water, and the carp have full digestive tract. High congestion, dark color and edema of the gills are in all cases the typical symptoms. The ammonia concentration in the blood plasma is increased from 5 to 10 times ( S vobodová et al. 1997,

Address for correspondence:

Prof. MVDr. Miriam Smutná, CSc.

Department of Biochemistry and Biophysics Faculty of Veterinary Hygiene and Ecology

University of Veterinary and Pharmaceutical Sciences

Palackého 1-3, 61242 Brno, Czech Republic
Phone: +420541562502

Fax. +420549243020

http://www.vfu.cz/acta-vet/actavet.htm 
2001; Červinka 2000). To prevent ammonia autointoxication it is important not to expose fish with full digestive tract (in particular diet with high nitrogen content) to stress factors such as e.g. a sudden decrease in water temperature or a decrease in water-dissolved oxygen (Čítek et al. 1998).

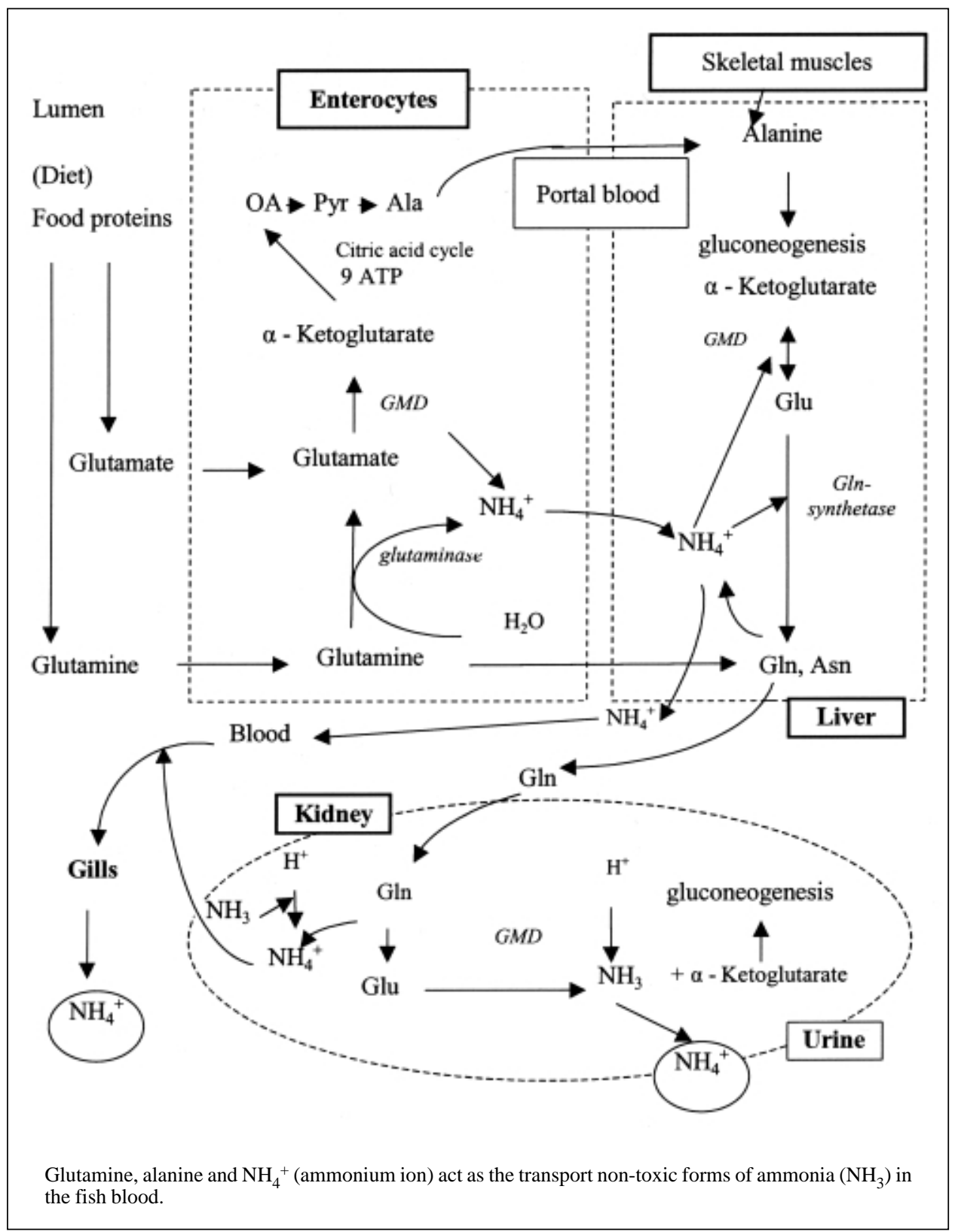

Fig. 1. The glutamine cycle. The role of glutamine in the transfer of amino groups between tissues. 
In order to prevent accidental mortality of carp caused by ammonia intoxication it is necessary to build the prevention measures on detailed knowledge on both endogenous ammonia sources and detoxication abilities in fish. This is the goal of the present review.

\section{Endogenous sources of ammonia in fish}

Both proteins and lipids dominate in the energy metabolism of teleosts. The intake of carbohydrates from food is variable (predatory versus non-predatory fishes) and the absorption of carbohydrates from the intestinal tract is limited due to the different kinds of feed (herbivorous species > omnivorous species > carnivorous species).

1. The role of the intestinal epithelial cells in ammonia production

The main purpose of food proteins is to provide the fish organism with necessary amino acids, important energy sources in tissues after deamination and decarboxylation. The majority of the absorbed amino acids proceed to the portal venous blood and is transported to the liver. The only exception is glutamine, which serves as a primary source of energy for the intestinal epithelial cells, which enables their proliferation, protein synthesis (both structural and functional: enzymes and transport proteins), further transport of nutrients, and the transport of ions and water. Both protein synthesis and transport require ATP, which may originate from the oxidation of amino acids as can be seen in Fig. 1. This is supported by the fact that the key enzyme glutamate dehydrogenase shows a higher activity in the gut than in the liver, as has been proved by Wilson (1973) in the channel catfish (Ictalurus punctatus). Glutamate dehydrogenase introduces glutamine and glutamate into the citric acid cycle in the form of $\alpha$-ketoglutarate. The following catabolism provides 9 molecules of ATP. It can be used partly as a source of energy for the intestinal epithelial cells (absorption and transport) and partly for their renovation. As can be seen in Fig. 1, the gut plays an important role in ammonia production (ammoniogenesis), as ammonia originates from both glutamine decomposition by glutaminase and oxidative deamination of glutamate caused by glutamate dehydrogenase.

The role of erythrocytes in ammonia metabolism

Circulating erythrocytes are responsible for the transport of amino acids such as tyrosine, phenylalanine, tryptophan, histidine, isoleucine and leucine under postprandial circumstances. These essential amino acids permeate easily from erythrocytes into the plasma and vice versa. The intracellular concentrations of the non-essential amino acids taurine, aspartate and glutamate are more than 10 times higher than the corresponding concentrations in the plasma (Ogata and Arai 1985). The erythrocytes in rainbow trout (Oncorhynchus mykiss) show a high activity of enzymes that are to a high extent involved in metabolism of amino acids (Ferguson and Storey 1991), such as glutamate dehydrogenase (GMD), aspartate aminotransferase (AST), and alanine aminotransferase (ALT). There is an intensive consumption of glutamine in erythrocytes of carp (Tiihonen and Nikinmaa 1991), which is from the energetic point of view more effective than oxidation of glucose (9 ATP in comparison with 2 ATP from glycolysis). Moreover, it shall be pointed out that in the course of hydrolytic decomposition of glutamine by glutaminase to glutamate, ammonia is produced (Fig. 1).

Constant uptake of amino acids from the circulation by all body cells of fish mainly in the postabsorptive phase (i.e. between food intakes) leads to generally low levels of proteinogenic free amino acids in the blood plasma. This was confirmed by Wilson and Poe (1974) in channel catfish (Ictalurus punctatus) where the total concentration of free amino acids in serum was low $\left(2.0 \mu \mathrm{mol} \cdot \mathrm{g}^{-1}\right)$, compared to liver $\left(130 \mu \mathrm{mol} \cdot \mathrm{g}^{-1}\right)$ and muscle $\left(16.5 \mu \mathrm{mol} \cdot \mathrm{g}^{-1}\right)$. Utilization of non-essential amino acids was more intensive than utilization of essential amino acids (Walton and Cowey 1982). 


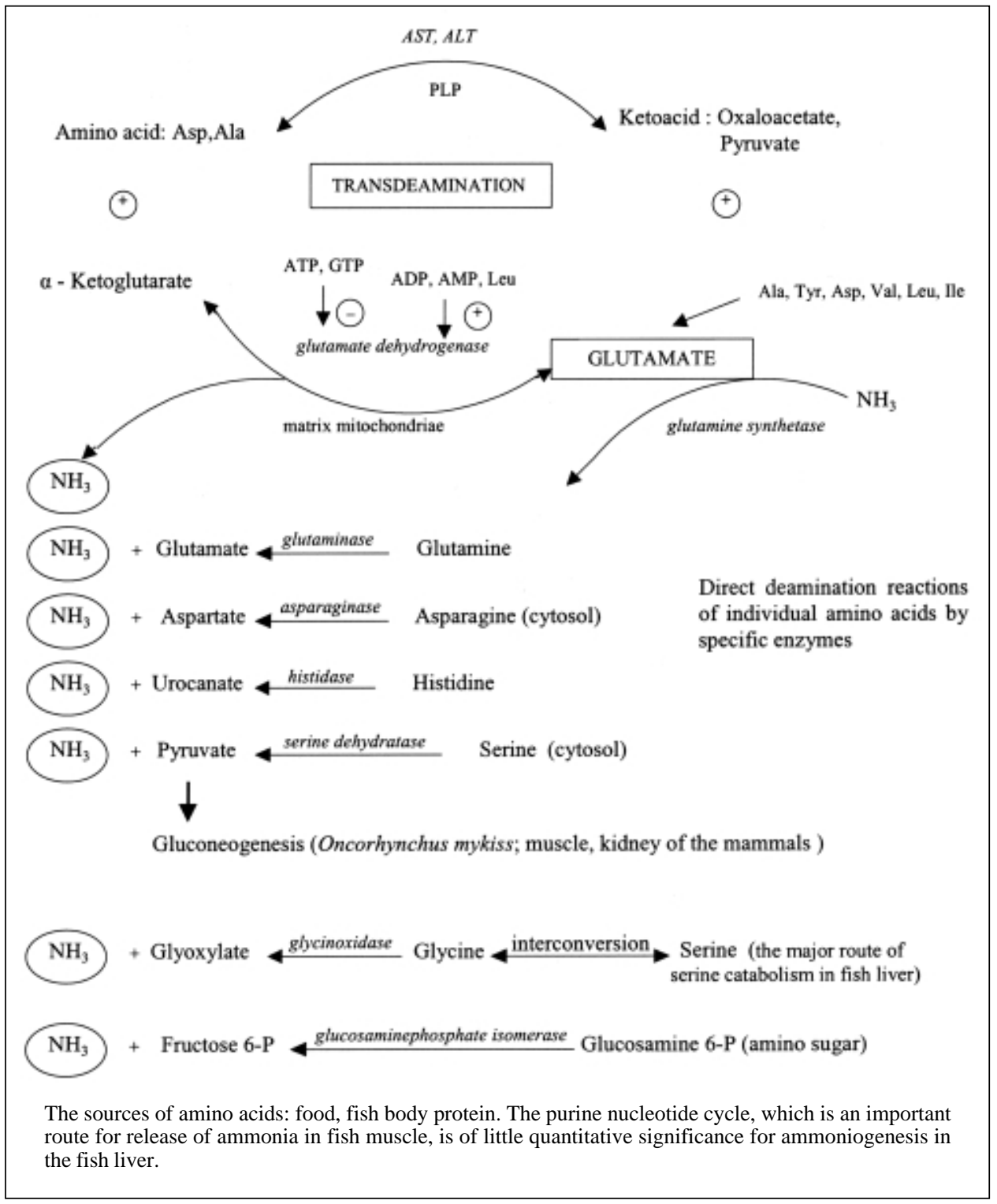

Fig. 2. Ammoniogenesis by transdeamination in the liver of fish.

2. The role of the liver in ammonia production and metabolism

The liver is significantly and permanently involved in the ammonia production in fish. This is confirmed by the fact that 50 to $70 \%$ of the total produced ammonia originates in the liver. The main metabolic pathway catalyzed by specific enzymes is direct deamination of amino acids that, besides the production of ammonia, provide precursors for both gluconeogenesis and lipogenesis in the fish liver (residual carbon skeleton) as can be seen 
in Fig. 2. Glutamate, glutamine and aspartate are involved in the deamination during the transdeamination process, which is catalyzed by glutamate dehydrogenase (Campbell et al. 1983). Conversion of the $\alpha$-amino groups to ammonia during transdeamination requires the activity of aminotransferases (ALT, AST) and glutamate dehydrogenase. Glutamate dehydrogenase is stimulated by ADP, AMP, and leucine and is inhibited by ATP and GTP (Hay a shi et al. 1982). Basic differences in ammonia economy between fish and mammals consist in the fact that in fish hepatic ammonia is mainly transported to the gills and less to the kidney for excretion whereas the mammalian liver converts ammonia to urea which is transported into the kidney for elimination.

The situation in the postabsorptive state is different in fish. Mainly kidney, muscles and gut contribute significantly to the ammonia pool (Van Waarde 1983).

\section{The role of the kidney in ammonia production and metabolism}

From the quantitative point of view the main process that produces ammonia in the fish kidney is deamination of amino acids (e.g. histidine) and transdeamination which is associated with transamination. The catalytical activities of three important transdeamination enzymes (glutamate dehydrogenase, aspartate aminotransferase, alanine aminotransferase) in the kidney of Ictalurus punctatus, Cyprinus carpio and Oncorhynchus mykiss are similar to those in the liver (Wils on 1973; Scheinert and Hoffmann 1987). From the partial reactions of further amino acids, deamination of glutamine (mainly), histidine and serine are of certain importance with regard to the ammonia production in the fish kidney as can be seen in Fig. 3. Ammonia $\left(\mathrm{NH}_{3}\right)$ produced in the kidney of fish is released into circulation as ammonium ion $\left(\mathrm{NH}_{4}^{+}\right)$and is eliminated from the fish body mainly through the gills. To a small extent it is also excreted in the urine (Randall and Wright 1987).

3. The role of the skeletal muscle in ammonia production

In most fish skeletal muscles constitute more than $50 \%$ of the whole body mass. Muscles concentrate the largest pool of free amino acids. In the red muscles mainly aerobic processes take place with high catalytic activities of enzymes such as AST, ALT, GMD and transaminases of branched-chain amino acids. Among these amino acids particularly leucine is of importance as a substrate for intensive working muscles. White muscles work in an anaerobic mode and require glycogen for their action. Glucose, promptly supplied by circulation is less significantly utilized in muscles due to the low activity of hexokinase, the first enzyme of the glycolysis (Knox et al. 1980). The red muscles have a larger capacity for the utilization of amino acids than the white muscles. However, the white muscles contain more proteins and serve as reservoir of amino acids for the season of starvation or migration of fish.

The amino acids glutamate, alanine, glycine, asparagine, glutamine and histidine are found in high concentrations in the skeletal muscles of fish. An extraordinary high concentration of free histidine is typical of the families Scombridae and Clupeidae. Besides histidine, muscles may contain also a high number of derivatives of histidine - carnosine (eel, tuna) and anserine (salmon, trout, tuna, blue marlin). These mentioned compounds serve as a buffering system and do not participate in energy metabolism and ammonia production (Abe 1983).

The spectrum of amino acids found in the fish muscles and the high activity of cooperative enzymes leads to the suggestion that the ammonia production takes place here by transdeamination as has been described for the liver and the kidney of fish. Partial deamination of individual amino acids important for the muscle function (glutamate, glutamine, aspartate, asparagine, histidine) contribute to this assumption. However, there is 


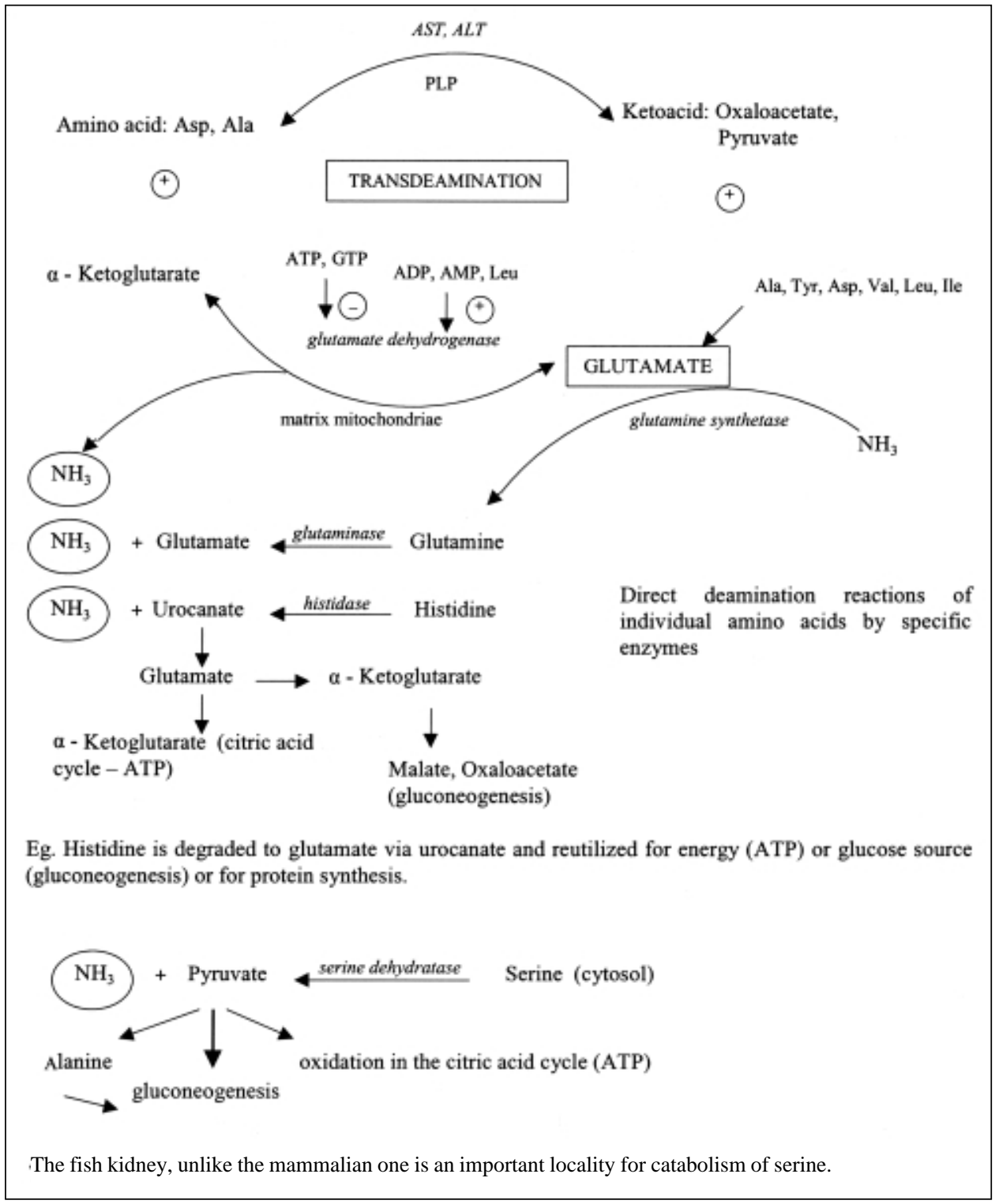

Fig. 3. Ammoniogenesis in the fish kidney.

another alternative pathway for the production of ammonia in fish muscles - the cycle of purine nucleotides (Fig. 4; Mommsen and Hochachka 1988).

In this cycle aspartate rises from oxaloacetate during transdeamination of glutamate. Aspartate enters the cycle of purine nucleotides. It reacts with inosine monophosphate (IMP) in the presence of guanosine triphosphate (GTP) thereby producing adenylosuccinate. Fumarate and adenosine monophosphate (AMP) are released from adenylosuccinate. 


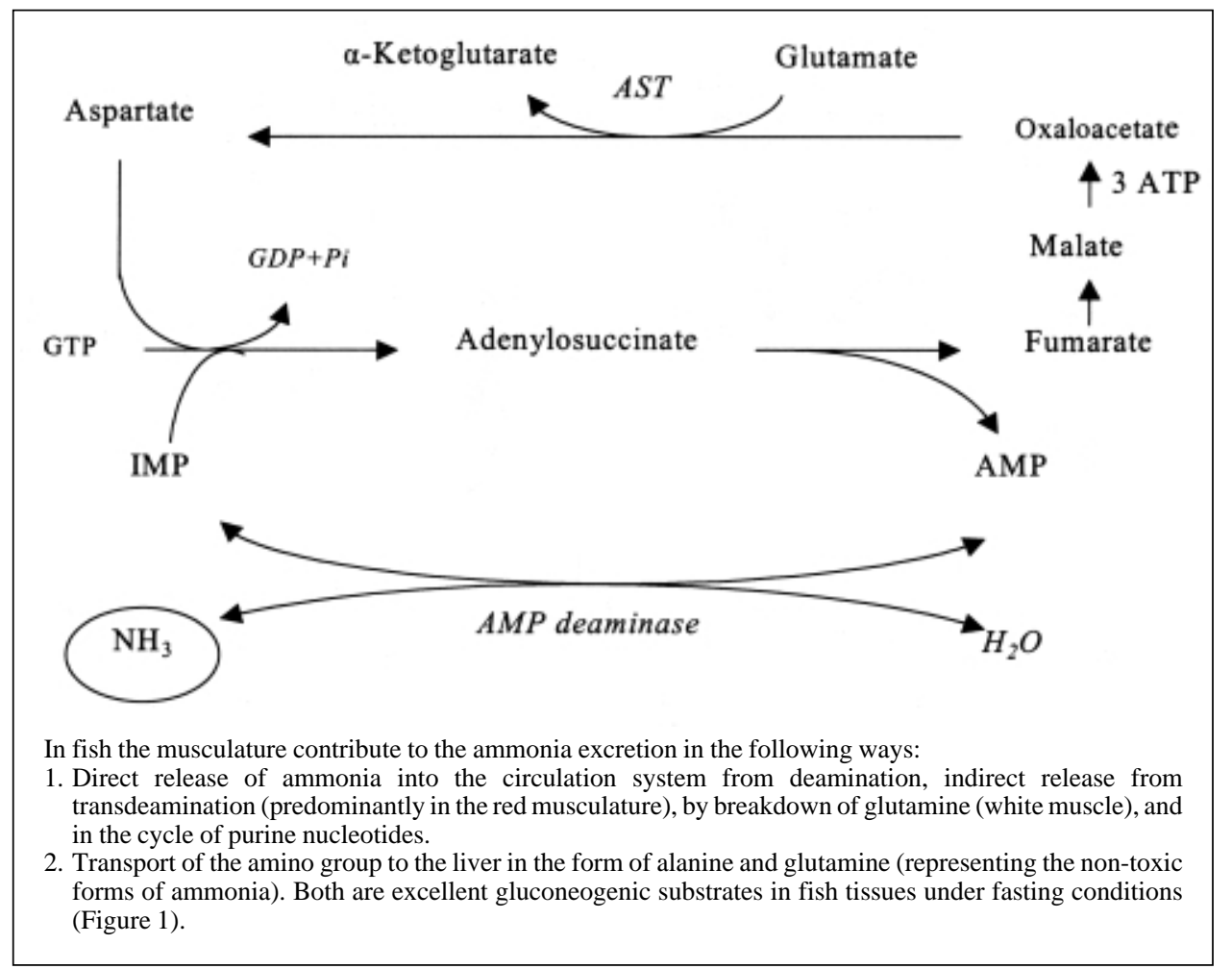

Fig. 4. Production of ammonia in the purine nucleotide cycle. Important pathways of ammoniogenesis in the muscle of fish.

Fumarate is converted to malate which is converted to oxaloacetate in the final phase of the citric acid cycle. Adenosine monophosphate is deaminated due to the catalyzing effect of adenylyl deaminase. Ammonia and IMP are produced and thus the cycle is closed.

The cycle of purine nucleotides in the skeletal muscle plays also an important metabolic role. Fumarate thus produced complement actually intermediates of the citric acid cycle in the muscle of fish. An increase in the activity of the citric acid cycle positively affects the muscle efficiency, due to the fact that a large amount of the produced ATP is available (Voet and Voet 1990; Murray et al. 2000).

The above mentioned findings imply that skeletal muscles of fish produce ammonia due to a direct release by deamination, an indirect release by transdeamination and transfer of ammonia to the circulation system (red muscle), by decomposition of glutamine (white muscle), and in the cycle of purine nucleotides (Fig. 4; V an Waarde 1983).

Alanine, glutamine and $\mathrm{NH}_{4}{ }^{+}$(ammonium ion) act as the transport non-toxic forms of ammonia in the fish blood. Both alanine and glutamine form excellent gluconeogenic substrates in fish tissues under fasting conditions (Fig. 1).

4. The ammonia production during burst (exhaustive) exercise in fish

The majority of ATP necessary for burst exercise of fish (attack on prey, escape from predators - active stress, migration against a fast stream of water) derives from the degradation of depot glycogen in white muscles and consequent glycolysis. Splitting of 
creatine phosphate by creatine kinase serves as another ATP source as can be seen in Fig. 5 . The reserves of creatine phosphate are not too large and they are soon exhausted due to the demand for ATP production. Production of an active actin-myosin complex, necessary for muscle contraction, leads to a splitting of ATP (myosin ATPase) in ADP and $\mathrm{P}_{\mathrm{i}}$. However ATP can be renewed using muscle adenylyl kinase (myokinase). Adenylyl kinase catalyses the production of one ATP molecule and one molecule of adenosin-5'-monophosphate (AMP) from two molecules of ADP. Finally the deamination of AMP leads to the production of IMP and ammonia:

$\mathrm{AMP}+\mathrm{H}_{2} \mathrm{O} \rightarrow \mathrm{IMP}+\mathrm{NH}_{3}$ (adenylyl deaminase, AMP deaminase)

This is in accordance with the final step within the cycle of purine nucleotides (Fig. 4). This pathway of ammonia production corresponds to that described for intensive working muscles in mammals (predator - prey interactions).

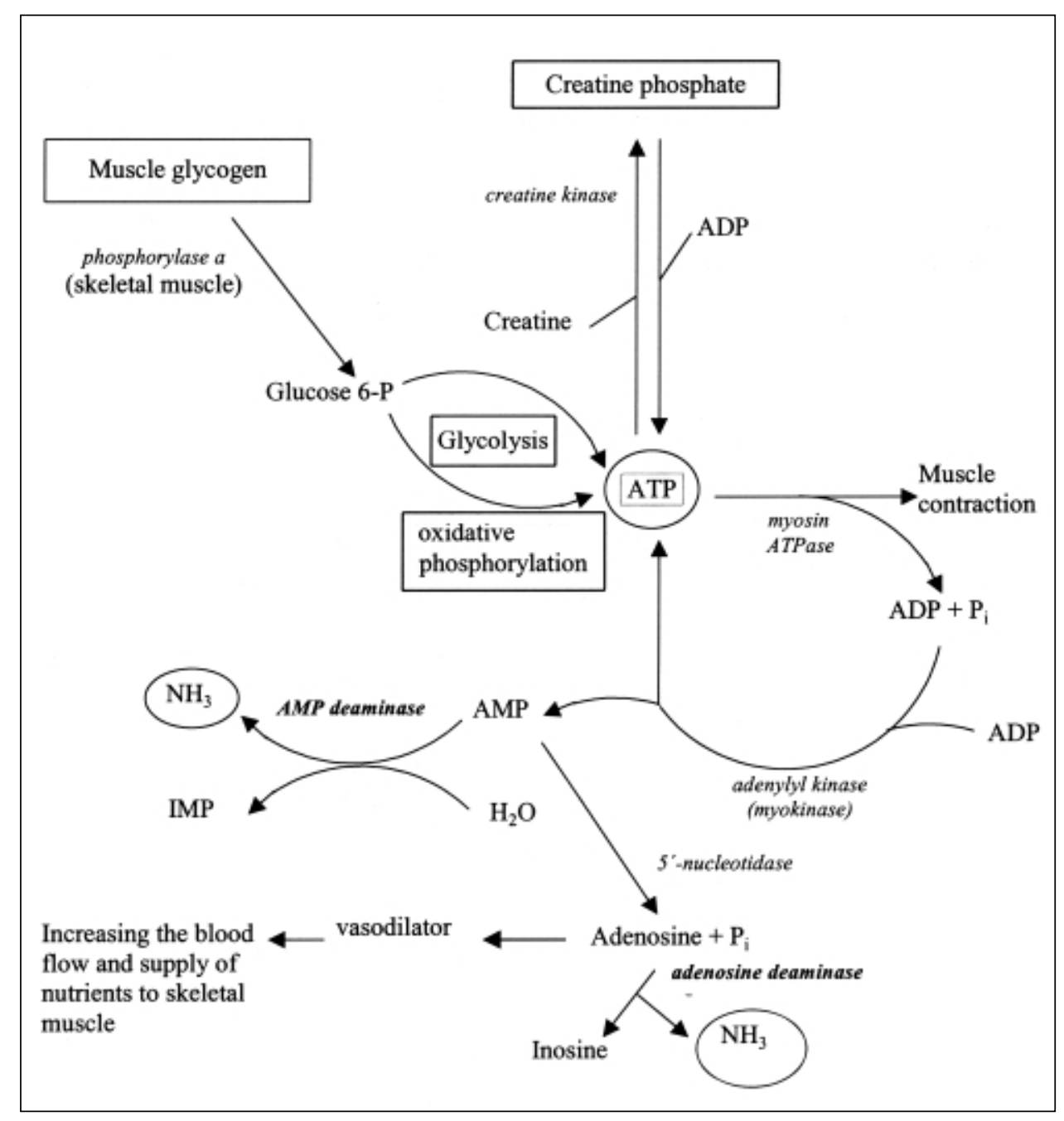

Fig. 5. Actual sources of ammonia in skeletal muscles of fish during burst (exhaustive) exercise. 
The AMP can also be further split by $5^{\prime}$-nucleotidase using equation:

$\mathrm{AMP}+\mathrm{H}_{2} \mathrm{O} \rightarrow$ adenosine $+\mathrm{P}_{\mathrm{i}}$

The produced adenosine causes vasodilatation leading to an increased blood flow and supply of nutrients to the skeletal muscle. On the other hand, adenosine represents the substrate for adenosine deaminase, leading again to the production of ammonia:

adenosine $+\mathrm{H}_{2} \mathrm{O} \rightarrow$ inosine $+\mathrm{NH}_{3}$

The metabolites AMP, $\mathrm{P}_{\mathrm{i}}$ and $\mathrm{NH}_{3}$ activate phosphofructokinase, the key enzyme of glycolysis, thus increasing the rate of glycolysis in the rapidly exercising muscle (Murray et al. 2000).

These findings imply that similar to mammals, in fish burst exercise causes production of ammonia.

It is vital during the burst exercise to maintain the intracellular $\mathrm{pH}$ of the skeletal muscles. Nitrogen driving from the structure of imidazole ring of free histidine and its derivatives methylhistidine, carnosine and anserine (Abe and Okuma 1991) contributes to this maintenance.

5. Further potential sources contributing to the endogenous ammonia pool in the fish body (derived upon deep knowledge on biochemistry and endogenous metabolism).

Following factors belong to further potential sources of ammonia:

- high protein diet

- catabolism of pyrimidines

- catabolism of purine nucleosides

- putrefaction of proteins from desquamated gut epithelium during times without feeding

- degradation of biogenic amines (products of amino acid decarboxylation)

- biosynthesis of hemoglobin (porphobilinogen deaminase)

- sudden decrease in environmental temperature followed by a retardation of enzymatic reactions

- salinity adaptations

6. The ammonia production during starvation

Fish survive for a long time without food and a starvation period is for many species a part of their life cycle. They mobilize body reserves (glycogen, lipids) and also structural components of tissues (amino acids) in order to survive long periods of starvation (winter, long migration during the reproduction).

Liver glycogen, a reserve form of carbohydrates, represents in fish 1-6\% of the total liver weight (in carp even more than 10\%). Liver glycogen is mobilized on demand, and after enzymatic split transported to the extrahepatic tissues as glucose. Glucose is metabolized or used for resynthesis of glycogen. This process takes place continuously during starvation periods. According to $\mathrm{Nav}$ arro et al. (1993), the glycogen content in the liver of trout (Salmo trutta fario) was $4.4 \%$ at the beginning and $0.6 \%$ at the end of starvation (50th day). Also muscle glycogen has been shown to decrease from $0.24 \%$ to $0.09 \%$ at the end of a 50 -day starvation. Glycogen was utilized faster in summer than in winter. In contrast, pacific salmons (Oncorhynchus nerka) migrating $1000 \mathrm{~km}$ revealed constant carbohydrate reserves (Fren ch et al. 1983). Similarly, eels (Anguilla anguilla) have been shown not to quantitatively change the reserves of liver glycogen after 95 days of starvation. However, these reserves were exhausted after 5 months of starvation (Lars son and Lewander 1973).

Generally, a normal glucosemia is maintained during starvation of fish (carp, eel). Both glycogenolysis in the liver (due to starvation) and proteolysis of muscle proteins resulting in mobilization of amino acids for gluconeogenesis in the liver act as stabilizing factors. 
From the amino acids of muscle mainly alanine enters the liver gluconeogenesis, to saturate the glucose reserves for long-lasting starvation (in terms of months). There is more intensive metabolism of alanine in migrating fish than in non-migrating fish. In fish, lactate as another typical substrate for gluconeogenesis in the mammalian liver, is processed during glycogen resynthesis in the white muscles directly (recovering period of muscles). Only a minimal amount of lactate proceeds to the liver (Moyes et al. 1992).

The chronological sequence of energy resources that can be mobilized in fish during starvation is as follows: carbohydrates, lipids (alternatively at same time) and finally mobilization and catabolism of proteins.

Black and Love (1986) found that the depot lipids in the liver (another important energy resource in fish) were rapidly decreased during starvation in Atlantic cod (Gadus morhua), whereas reserve of glycogen were not changed. In carp after 100 days lasting experimental starvation, the glycogen level in the hepatopancreas was $1.6 \%$, whereas the lipids were totally exhausted (Nagai and Ikeda 1971). Similar results were reported in rainbow trout (Oncorhynchus mykiss) and in pike (Esox lucius) by Jezierska et al. (1982), Ince and Thorpe (1976). The situation is different in fish having energy reserves in their visceral fat e.g. sea bass (Dicentrarchus labrax). In such fish lipid reserves in the liver were not affected even after starvation for 22 or 130 days (Gutiérrez et al. 1991).

Ketone bodies (an alternative energy source for skeletal muscle in mammals) do not play any important role in starving fish. Fish miss the key enzyme for the production of ketone bodies (3-hydroxybutyrate dehydrogenase) in the liver. The ability to utilize acetoacetate (an other ketone body) in the muscles is also very limited in fish (Beis et al. 1980).

A high activity of proteolytic enzymes in the muscle of fish (cathepsines, carboxypeptidases) enables the mobilization of proteins during starvation. This is associated with the ability of fish to excrete nitrogen in the form of ammonia or ammonium ion. There are only few ureotelic fish, e.g. tilapia (Oreochromis alcalicus grahami). This fish has a functional ureosynthetic cycle, lives in extremely alkaline environment (Lake Magadi, $\mathrm{pH}$ 10; Randall et al. 1989).

Muscles in carp show in the early phase of starvation the lowest proteolytic activity. The activity increases in the following order: spleen < liver < kidney < gut. If the period of starvation lasts longer the situation changed to that the gut shows the lowest proteolytic activity and the activity increases in the following order: liver $<$ kidney $<$ spleen $<$ white muscles. White muscles respond to starvation in the most sensitive way, showing a decrease of proteosynthesis, whereas in the liver and in the gills proteosynthesis is affected by starvation to a very small extent only (Pocrnjic et al. 1983). E.g. levels of histidine were significantly decreased in white muscles of eel and rainbow trout during starvation for 200 and 62 days, respectively (Kawai and Sakaguchi 1968; Hochachka and Mommsen 1995). It can be seen from the general metabolism of histidine (Fig. 3) that it represents either a direct source of energy for the skeletal muscle or a source of glucose (metabolite $\alpha$-ketoglutarate), or it can enter proteosynthesis (metabolite glutamate). Concentrations of plasma proteins decline during starvation as follows: At first a decrease of albumin occurs followed by a decrease of $\alpha$ - and $\beta$-globulins, whereas $\gamma$-globulins are not utilized at all. Essential amino acids are utilized by the tissues during short lasting starvation ( 24 or $48 \mathrm{~h}$ ), e.g. in rainbow trout or in carp. In carp, after 5 days of starvation even branched-chain amino acids in plasma were utilized and a re-increase of the concentrations of these amino acids due to decomposition of muscle proteins was recorded after 19 days (Hochachka and Mommsen 1995).

\section{Conclusion}

Ammonia is toxic for all animals. The main source of ammonia in fish is represented by deamination of amino acids that occurs mainly in the liver, kidney, muscle and gut. A high 
production of ammonia during the common life of fish (natural locomotion, burst exercise, migration, starvation) and the inability to get off ammonia using ureosynthetic cycle (which is typical for mammals, adult amphibians and elasmobranch fishes) requires a high activity of the excretory organs - the gills and the kidney. An extraordinary body metabolism of histidine, and serine, including a summation of small ammonia sources during restoration of body tissues and cells contributes significantly to an endogenous pool of ammonia. Changes in environmental conditions can easily move the balance between endogenous ammonia concentrations and excretion. When the detoxication abilities of the fish are exceeded, ammonia acts as a toxicant.

Despite the potential toxicity, it is necessary to mention the physiological need for ammonia in fish. Ammonia is fixed in a molecule of carbamoyl phosphate required for pyrimidine biosynthesis. Ammonia is also important as a component of the molecule glutamine, because glutamine acts as a donor of amino groups to support pyrimidine and purine synthesis (construction of DNA, RNA, coenzymes). Glutamine also supports the building of amino sugars (cartilages, mucus of fish) and folacin (coenzyme in the metabolism of serine). The fish kidney, unlike the mammalian one, is an important locality for the catabolism of serine, thereby contributing to the endogenous ammonia pool (W alt on and Cowey 1981). In contrast the mammalian kidney releases this amino acid into the circulation to reach the liver and muscles (oxidation in the citric acid cycle or gluconeogenesis; Murray et al. (2000).

\section{Patobiochemie amoniaku ve vnitřním prostředí ryb (přehled)}

Ve studii jsou analyzovány zdroje vzniku a cesty detoxikace amoniaku v těle ryb. Amoniak je pro organismus toxický i ve stopovém množství. Z hlediska produkce amoniaku je vyzdvižena role přímé deaminace aminokyselin se zaměřením na histidin, serin, asparagin, glutamin. Funkční spojení transaminace a deaminace se odráží v transdeaminační reakci, kde centrální úlohu hraje enzym glutamátdehydrogenasa. Studie objasňuje i další, méně známé zdroje amoniaku při přirozené obnově tělesných buněk a tkání. Zesumarizovaná specifika biochemických procesů u ryb, neexistence ureosyntetického cyklu a náhlá změna podmínek vnějšího prostředí velmi lehce mohou posunout rovnováhu nabídky a exkrece do stavu převyšujícího detoxikační možnosti rybího organismu a amoniak se pak projeví toxicky, např. v havarijním úhynu ryb.

\section{Acknowledgments}

This work was supported by the Ministry of Education, Young and Sports of the Czech Republic, grant No. 162700005

\section{References}

ABE, H 1983: Distribution of free L-histidine and its related compounds in marine fishes. Bull Jpn Soc Sci Fish 49: $1683-1687$

ABE, H, OKUMA, E 1991: Effect of temperature on the buffering capacities of histidine-related compounds and fish skeletal muscle. Bull Jpn Soc Sci Fish 57: 2101-2107

BEIS, A, ZAMMIT, A, NEWSHOLME, EA 1980: Activities of 3-hydroxybutyrate dehydrogenase, 3-oxoacid CoA-transferase and acetoacetyl-CoA thiolase in relation to ketone body utilization in muscle from vertebrates and in invertebrates. Eur J Biochem 104: 209-215

BLACK, D, LOVE, RM 1986: The sequential mobilization and restoration of energy reserves in tissues of Atlantic cod during starvation and refeeding. J Comp Physiol 156B: 469-479

CAMPBELL, JW, ASTER, PL, VORHABEN, JE 1983: Mitochondrial ammoniagenesis in liver of the channel catfish (Ictalurus punctatus). Am J Physiol 244: R709-R717

ČERVINKA, S 2000: Personal communication.

ČÍTEK, J, SVOBODOVÁ, Z, TESARČÍK, J. 1998: Nemoci sladkovodních a akvarijních ryb. Informatorium Praha, $218 \mathrm{p}$.

DOEGE, A 1991: Environmental conditions of carp pond culture during an outbreak of necrotic gill disease. Fisch Teichwirt 42: 392-394 
FARKAS, J, OLAH, J 1986: Gill necrosis - a complex disease of carp. Aquaculture 58: 17-26.

FERGUSON, RA, STOREY, KB 1991: Glycolytic and associated enzymes of rainbow trout (Oncorhynchus mykiss) red cells: in vitro and in vivo studies. J Exp Biol 155: 469-485

FRENCH, C. J., HOCHACHKA, T. P., MOMMSEN, T. P. 1983: Metabolic organization of liver during spawning migration of sockeye salmon. Am. J. Physiol 245: R827-R830

GUTIÉRREZ, J, PÉREZ, J, NAVARRO, I, ZANUY, S, CARRILLO, M 1991: Changes in plasma glucagon and insulin associated with fasting in sea bass (Dicentrarchus labrax). Fish Physiol Biochem 9: 107-112

HAMORY, G, POCSI, L 1982: Preliminary studies on the course and etiology of gill necrosis of carp (Cyprinus carpio L.). Aquacult Hung 3: 99-104

HAYASHI, S, KUNIHIRO, K, ITAKURA, T, OOSHIRO, Z 1982: Biochemical properties of glutamate dehydrogenase purified from eel liver. Bull Jpn Soc Sci Fish 48: 697-701

HOCHACHKA, PW, MOMMSEN, TP 1995: Metabolic Biochemistry (Biochemistry and molecular biology of fishes). 1. ed. Elsevier, Amsterdam, 515 p.

HORNICH, M., TOMÁNEK, J 1983: Processes in carp gill tissue caused by changes in the aquatic medium. Vet Med Praha 28: 621-633

INCE, BW, THORPE, A 1976: The effects of starvation and force-feeding on the metabolism of the northern pike, Esox lucius L. J Fish Biol 8: 79-88

JEZIERSKA, B, HAZEL, JR, GERKING, SD 1982: Lipid mobilization during starvation in the rainbow trout, Salmo gairdneri R., with attention to fatty acids. J Fish Biol 21: 681-692

KAWAI, A, SAKAGUCHI, M 1968: Histidine metabolism in fish - II. Formation of urocanic, formiminoglutamic, and glutamic acids from histidine in the livers of carp and mackerel. Bull Jpn Soc Sci Fish 34: 507-511

KNOX, D, WALTON, MJ, COWEY, CB 1980: Distribution of enzymes of glycolysis and gluconeogenesis in fish tissues. Mar Biol 56: 7-10

KOVACS-GAYER, E’1984: Histopathological diagnosis of gill changes with special regard to gill necrosis. In: Olah, J (Ed): Fish, Pathogens and Environment in European Polyculture 23: 219-229

LARSSON, AC, LEWANDER, K 1973: Metabolic effects of starvation in the eel (Anguilla anguilla L.). Comp Biochem Physiol 44A: 367-374

LLOYD, R 1992: Pollution and freshwater fish. Fishing News Books, 176 p.

MOMMSEN, TP, HOCHACHKA, PW 1988: The purine cycle as two temporally separated metabolic units: a study on trout muscle. Metabolism 37: 552-556

MOYES, CD, SCHULTE, PM, HOCHACHKA, PW 1992: Recovery metabolism of trout white muscle: the role of the mitochondria. Am J Physiol. 262: R295-R304

MURRAY, R, GRANNER, DK, MAYES, PA, RODWELL, VW 2000: Harper's Biochemistry. 25th Edition, Appleton \& Lange, Stamford, $927 \mathrm{p}$

NAGAI, M, IKEDA, S 1971: Carbohydrate metabolism in fish. I. Effects of starvation and dietary composition on the blood glucose level and the hepatopancreatic glycogen and lipid content in carp. Bull Jpn Soc Sci Fish 37 404-410

NAVARRO, I, CARNEIRO, MN, PÁRRIZAS, M, MAESTRO, JL, PLANAS, J, GUTIÉRREZ, J 1993: Postfeeding levels of insulin and glucagon in trout (Salmo trutta fario). Comp Biochem Physiol 104A: 389-393

OGATA, H, ARAI, S 1985: Comparison of free amino acid contents in plasma, whole blood and erythrocytes of carp, coho salmon, rainbow trout, and channel catfish. Bull Jpn Soc Sci Fish 51: 1181-1186

POCRNJIC, Z, MATHEWS, RW, RAPPAPORT, S, HASCHMEYER, AEV 1983: Quantitative protein synthetic rates in various tissues of a temperate fish in vivo by the method of phenylalanine swamping. Comp Biochem Physiol 74B: $735-738$

RANDALL, DJ, WRIGHT, RA 1987: Ammonia distribution and excretion in fish. Fish Physiol Biochem 3: $107-$ 120

RANDALL, DJ, WOOD, CM, PERRY, SF, BERGMAN, H, MALOIY, GMO, MOMMSEN, TP, WRIGHT, PA 1989: Urea excretion as a strategy for survival in a fish living in a very alkaline environment. Nature 337: 165166

SCHEINERT, P, HOFFMANN, R 1987: Qualitative und quantitative Verteilung von sieben Enzymen in Organen der Regenbogenforelle (Salmo gairdneri R.) und des Karpfens (Cyprinus carpio). J Vet Med A 34: $339-343$

SCHRECKENBACH, K, SPANGENBERG, R, KRUG, S 1975: Die Ursache Kiemennekrose. Z Binnenfisch 22: 257-288

SVOBODOVÁ, Z, FAINA, R, GROCH, L, MÁCHOVÁ, J 1986: Study on the etiology of the toxic necrosis of carp gills. Bul VÚRH Vodňany 22: 3-13

SVOBODOVÁ, Z, GROCH, L, MÁCHOVÁ, J, FAINA, R, VYKUSOVÁ, B, SMOLÍKOVÁ, B. 1997: Případy havarijních úhynů kaprů v důsledku autointoxikace amoniakem. In: Kolářová et al.: Ochrana zdraví ryb, VÚRH JU Vodňany, pp. 185-193

SVOBODOVÂ, Z, SMUTNÁ, M, MÁCHOVÁ J, GROCH, L 2001: Úhyn tržních kaprů na sádkách. (Kill of marketable common carp in storage ponds). In: Kolářová et al.: Ochrana zdraví ryb, VÚRH JU Vodňany, 'pp. 113-118

TIIHONEN, K, NIKINMAA, M 1991: Substrate utilization by carps (Cyprinus carpio) erythrocytes. J Exp Biol 161: $509-514$ 
VAN WAARDE, A 1983: Aerobic and anaerobic ammonia production by fish. Comp Biochem Physiol 74B: 675-684

VOET, D, VOET, JG 1990: Biochemie. Victoria Publishing, Praha, 1325 p.

WALTON, MJ, COWEY, CB. 1981: Distribution and some kinetic properties of serine catabolizing enzymes in rainbow trout Salmo gairdneri. Comp Biochem Physiol 68B: 147-150

WALTON, MJ, COWEY, CB 1982: Aspects of intermediary metabolism in salmonid fish. Comp Biochem Physiol 73B: $59-79$

WILSON, RP 1973: Nitrogen metabolism in channel catfish, Ictalurus punctatus - I. Tissue distribution of aspartate and alanine aminotransferases and glutamic dehydrogenase. Comp Biochem Physiol 46B: 617-624

WILSON, RP, POE, WE 1974: Nitrogen metabolism in channel catfish, Ictalurus punctatus. - III. Relative pool sizes of free amino acids and related compounds in various tissue of the catfish. Comp Biochem Physiol 45B: 545-556

WOOD, CM 1993: Ammonia and urea metabolism and excretion. In: Ewans, DH (Ed) Physiology of Fishes. CRC Press Boca Raton, pp. 379-425.

\section{Abbreviations}

$\mathrm{ADP}=$ Adenosine diphosphate $;$ Ala $=$ Alanine $;$ ALT $=$ Alanine aminotransferase $;$ AMP $=$ Adenosine monophosphate; Asn = Asparagine; Asp = Aspartic acid (Aspartate) AST $=$ Aspartate aminotransferase $;$ ATP $=$ Adenosine triphosphate; GDP = Guanosine diphosphate; Gln = Glutamine; Glu = Glutamic acid (Glutamate); $\mathrm{GMD}=$ Glutamate dehydrogenase; GTP = Guanosine triphosphate; Ile = Isoleucine; IMP = Inosine monophosphate $; \mathrm{Leu}=$ Leucine $; \mathrm{OA}=$ Oxaloacetic acid (Oxaloacetate) $; \mathrm{P}_{\mathrm{i}}=$ Inorganic phosphate $; \mathrm{PLP}=\mathrm{Pyridoxal}$ phosphate; Pyr = Pyruvate; Tyr $=$ Tyrosine; Val = Valine . 